\title{
Peningkatan Aktivitas dan Hasil Belajar Materi Perubahan Lingkungan Fisik Melalui Model Pembelajaran Time Token Berbasis Media Flashcard
}

\section{Ismayanti* $^{*}$}

SD Nganguk Kudus

\section{A R T I C L E I N F O}

Article history:

Received 12 December

2019

Received in revised form

01 January 2020

Accepted 30 January 2020

Available online 27

February 2020

\section{Kata Kunci:}

Aktivitas, Hasil Belajar,

Model Time Token, Media

Flashcard

Keywords:

Activities, Learning

Outcomes, Time Token

Model, Flashcard Media

\begin{abstract}
A B S T R A K
Penelitian bertujuan untuk meningkatkan aktivitas dan hasil belajar IPA materi perubahan lingkungan fisik melalui model pembelajaran Time Token Berbasis Media Flashcard pada siswa kelas IV SD Nganguk semester II tahun pelajaran 2016/2017. Prosedur pelaksanaan dan implementasi di lokasi penelitian terbagi dalam dua siklus. Siklus I dilakukan dua kali pertemuan dan begitu juga siklus II dilakukan dua kali pertemuan. Hasil penelitian ini menunjukkan bahwa aktivitas belajar siswa pada siklus I memperoleh rata-rata skor 17,61 atau sebesar $73,38 \%$ (sedang), siklus II meningkat menjadi 21,45 atau sebesar $89,35 \%$ (sangat tinggi). Pada akhir tindakan siklus I nilai ratarata yang diperoleh 73,61 atau sebesar $72,22 \%$ mengalami peningkatan $16,66 \%$ dari kondisi awal. Nilai rata-rata siklus II diperoleh 82,22 atau sebesar $83,33 \%$ ketuntasan belajar sehingga mengalami peningkatan sebesar $11,11 \%$ dari siklus I. disimpulkan bahwa penerapan model pembelajaran time token berbasis media flashcard dapat meningkatkan aktivitas dan hasil belajar IPA materi perubahan lingkungan fisik pada siswa kelas IV SD Nganguk Kudus.
\end{abstract}

\section{A B S T R A C T}

The study aims to improve the activities and learning outcomes of natural science material changes in the physical environment through the learning model of Flashcard Media-Based Time Tokens in fourth grade students of Nganguk Elementary School in the second semester of the 2016/2017 school year. The procedure of implementation and implementation at the study site is divided into two cycles. Cycle I held two meetings and so did cycle II held two meetings. The results of this study indicate that the learning activities of students in the first cycle obtained an average score of 17.61 or of $73.38 \%$ (moderate), the second cycle increased to 21.45 or $89.35 \%$ (very high). At the end of the first cycle of action the average value obtained by 73.61 or $72.22 \%$ increased $16.66 \%$ from the initial conditions. The average value of cycle II was obtained 82.22 or $83.33 \%$ mastery learning so that it increased by $11.11 \%$ from cycle $l$. It was concluded that the application of time token learning models based on flashcard media could increase the activities and learning outcomes of natural science material on environmental change physical condition for fourth grade students of Nganguk Kudus Elementary School. 


\section{Pendahuluan}

Pendidikan merupakan bagian yang sangat penting dalam proses pembangunan suatu bangsa dan negara, karena tanpa didukungnya pendidikan tidak mungkin pembangunan suatu bangsa dan negara dapat berkembang dengan baik. Kita dapat melihat contohnya yaitu perkembangan antara desa dengan kota, dimana kota bisa dianggap lebih berkembang dari pada desa dikarenakan sistem pembangunan yang dipimpin oleh orang-orang terpelajar. Pendidikan itu sebenarnya harus didapatkan oleh setiap lapisan masyarakat agar pembangunan suatu bangsa dan negara itu dapat berjalan dengan baik. Hal tersebut juga terlihat dalam UUD 1945 pasal 31 yang menyatakan bahwa setiap warga negara berhak mendapatkan pendidikan (Amandemen UUD 1945, Bab XIII tentang Pendidikan dan Kebudayaan). Pernyataan dalam pasal 31 itu sekaligus merupakan landasan dan jaminan bagi setiap warga negara Indonesia untuk memperoleh pendidikan tanpa membedakan suku, agama, dan golongan (Sirait, 2016).

Pendidikan juga merupakan kegiatan terencana yang berlangsung sepanjang hidup dan menjadi kebutuhan bagi manusia. Pendidikan tidak hanya berlangsung di sekolah, akan tetapi dapat juga berlangsung di dalam keluarga dan masyarakat. Oleh karena itu, pendidikan menjadi tanggung jawab bersama antara keluarga, masyarakat, dan juga pemerintah. Pendidikan memegang peranan penting bagi kehidupan manusia. Tanpa pendidikan manusia akan sulit berkembang atau bahkan tidak berkembang. Dengan demikian, pendidikan harus benar benar diarahkan agar menghasilkan manusia yang berkembang dan berkualitas serta mampu bersaing, di samping memiliki akhlak dan moral yang baik (Ayuwanti, 2016).

Pendidikan Dalam proses pembelajaran IPA di SD Nganguk Kudus, guru belum mendorong siswa untuk berpartisipasi aktif dalam pembelajaran, dengan demikian peran guru lebih dominan. Selain itu, kurangnya memanfaatkan alat peraga dan lingkungan sekitar dalam usaha membuat pembelajaran lebih bermakna. Maka dari itu, guru dapat menggunakan berbagai macam media, metode, model, maupun strategi yang lebih variatif dan tepat guna agar tujuan pembelajaran dapat tercapai sesuai indikator keberhasilan yang telah dirumuskan.

Pembelajaran IPA yang banyak berkembang tetap didasarkan pada teori-teori belajar. Teori-teori belajar tersebut haruslah dipelajari dengan sungguh-sungguh guna menghindari adanya kesalahan atau kekeliruan dalam penerapannya. Teori-teori belajar akan menjadi tidak berguna manakala makna dari konsep-konsep yang dikembangkan tidak dipahami dengan baik.

Robbins dalam Trianto (2012:15) mendefinisikan belajar sebagai proses menciptakan hubungan pengetahuan yang sudah dipahami dengan pengetahuan yang baru. Dari definisi ini, dimensi belajar memuat beberapa unsur, yaitu: (1) penciptaan hubungan, yaitu pengetahuan yang lama dan yang baru, (2) pengetahuan yang sudah dipahami, dan (3) sesuatu pengetahuan yang baru. Jadi dalam makna belajar, bukan berangkat dari sesuatu yang benar-benar belum diketahui oleh siswa, tetapi merupakan keterkaitan dari dua pengetahuan yang sudah ada dengan pengetahuan baru.

Menurut Rifa'i dan Anni (2011:82) belajar merupakan proses penting bagi perubahan perilaku setiap orang dan belajar itu mencakup segala sesuatu yang dipikirkan dan dikerjakan oleh seseorang. Belajar memegang peranan penting dalam perkembangan, kebiasaan, sikap, keyakinan, tujuan, kepribadian, dan bahkan persepsi seseorang. Oleh karena itu, dalam menguasai konsep dasar tentang belajar, seseorang mampu memahami bahwa aktivitas belajar itu memegang peranan penting dalam proses psikologis.

Selanjutnya, aktivitas belajar adalah segala kegiatan yang dilakukan dalam proses interaksi antara guru dan siswa dalam pembelajaran. Banyak aktivitas yang dapat dilakukan oleh siswa di sekolah. Aktivitas siswa tidak cukup hanya mendengarkan dan mencatat seperti yang lazim terdapat pada sekolahsekolah tradisional. Sardiman (2011:100) menyatakan "aktivitas belajar adalah aktivitas fisik juga mental. Dalam kegiatan belajar kedua ativitas itu harus selalu terkait”. Kaitan antar keduanya akan membuahkan aktivitas belajar yang optimal.

Implementasi dari belajar dan aktivitas belajar adalah hasil belajar. Dalam mengikuti pembelajaran di sekolah setiap siswa mengharapkan hasil belajar yang baik. Hasil belajar yang baik dapat tercapai apabila dalam proses pembelajaran juga baik. Dalam proses pembelajaran ada beberapa komponen yang sangat mempengaruhi hasil belajar salah satunya guru dan siswa. Dimyati dan Mudjiono (2010: 250-1) menjelaskan hasil belajar merupakan hal yang dapat dipandang dari dua sisi, yaitu dari sisi siswa dan guru. Dari sisi siswa, hasil belajar merupakan tingkat perkembangan mental yang lebih baik bila dibandingkan pada saat sebelum belajar. Tingkat perkembangan mental tersebut terwujud pada jenisjenis ranah kognitif, afektif, dan psikomotor. Sementara itu, dari sisi guru, hasil belajar merupakan terselesaikannya bahan pelajaran.

Rifa"i dan Anni (2011:85) menyatakan hasil belajar merupakan perubahan perilaku yang diperoleh siswa setelah mengalami kegiatan belajar. Perolehan aspek-aspek perubahan perilaku tersebut 
tergantung pada apa yang dipelajari oleh siswa. Selanjutnya, klasifikasi hasil belajar dari Benjamin Bloom dalam Rifa'i dan Anni (2011:86-87) yang secara garis besar membaginya menjadi tiga ranah yakni ranah kognitif, ranah afektif, dan ranah psikomotor.

Hasil belajar siswa merupakan salah satu tujuan dari proses pembelajaran di sekolah, untuk itu seorang guru perlu mengetahui, mempelajari beberapa metode mengajar, serta dipraktekkan pada saat mengajar. Untuk menghasilkan prestasi (hasil) belajar siswa yang tinggi, guru dituntut untuk mendidik dan mengajar siswa dengan menggunakan metode pembelajaran yang dibutuhkan dalam proses pembelajaran di kelas. Djamarah dan Zain (2010) menyebutkan bahwa kedudukan metode adalah sebagai alat motivasi ekstrinsik, sebagai strategi pengajaran dan juga sebagai alat untuk mencapai tujuan (Nasution, 2017).

Berdasarkan data hasil tes formatif pembelajaran IPA materi perubahan lingkungan fisik pada tanggal 6 Februari 2017 dapat diketahui bahwa siswa belum mampu menyerap dan memahami materi secara maksimal. Hal tersebut dibuktikan dengan hasil tes yang dilakukan guru sebagai evaluasi dengan ketetapan nilai KKM sebesar 70 untuk mata pelajaran IPA, terdapat $8(44,44 \%)$ dari 18 siswa, belum memenuhi KKM. Berdasarkan hasil analisis pembelajaran yang dilakukan guru kelas IV, bahwa hal demikian terjadi karena siswa sulit diajak ikut serta aktif dalam pembelajaran. Siswa merasa bosan dan kurang tertarik dengan pembelajaran yang telah disampaikan serta pemahaman siswa terhadap materi menjadi kurang optimal sehingga berpengaruh terhadap hasil belajar siswa.

Salah satu upaya yang dapat dilakukan untuk meningkatkan kualitas pembelajaran yaitu menerapkan model pembelajaran yang sesuai dengan materi dan kondisi lingkungan sekitar, yaitu model pembelajaran Time Token berbasis media flashcard.

Model pembelajaran Time Token berbasis media flashcard digunakan untuk mengembangkan keterampilan sosial serta meningkatkan kemampuan siswa dalam berkomunikasi dan mengajarkan siswa untuk menghargai pendapat orang lain. Selain itu, siswa akan diberi kebebasan untuk bertanya atau menjawab pertanyaan, berpendapat maupun menanggapi pendapat orang lain sehingga diharapkan dapat memberikan pengaruh positif terhadap aktivitas dan hasil belajar siswa.

Model pembelajaran Time token merupakan model pembelajaran yang bertujuan agar setiap anggota diskusi mendapatkan kesempatan untuk memberikan kontribusi dan mendengarkan pandangan orang lain. Menurut Arends sebagaimana dikutip dalam Huda (2013:239) strategi pembelajaran Time token merupakan salah satu contoh kecil dari penerapan pembelajaran demokratis di sekolah. Proses pembelajaran demokratis adalah proses belajar yang menempatkan siswa sebagai pusat pembelajaran. Dalam prosesnya sepanjang pembelajaran aktivitas siswa menjadi perhatian utama. Dengan kata lain mereka selalu dilibatkan secara aktif. Guru berperan sebagai fasilitator dan mengajak siswa mencari solusi bersama terhadap permasalahan yang ditemui dalam kehidupan sehari-hari.

Huda (2013:241) menjelaskan model Time Token memiliki beberapa kelebihan dan kekurangan dalam pelaksanaannya. Beberapa kelebihan strategi Time token antara lain: (1) mendorong siswa untuk meningkatkan inisiatif dan partisipasi; (2) menghindari siswa yang pandai berbicara atau yang tidak berbicara lagi; (3) membantu siswa untuk aktif dalam kegiatan pembelajaran; (4) meningkatkan kemampuan siswa dalam berkomunikasi (aspek berbicara); (5) melatih siswa untuk mengungkapkan pendapat; (6) menumbuhkan kebiasaan pada siswa untuk saling mendengarkan, berbagi, memberikan masukan, dan memiliki sikap keterbukaan terhadap kritik; (7) mengajarkan siswa untuk menghargai pendapat orang lain; (8) mengajak siswa mencari solusi bersama terhadap permasalahan yang dihadapi; (9) dan tidak memerlukan banyak media pembelajaran.

Penerapan model time token dalam pembelajaran IPA akan lebih efektif apabila didukung dengan media yang sesuai dengan materi pelajaran agar proses penyampaian pesan dari guru dapat diterima siswa dengan optimal. Media yang digunakan dalam penelitian ini adalah media flashcard untuk mempermudahkan memahami materi yang disampaikan guru dalam kegiatan pembelajaran. Flashcard adalah media pembelajaran dalam bentuk kartu bergambar yang berukuran $25 \times 30 \mathrm{~cm}$. Gambargambarnya dapat dibuat menggunakan tangan/foto, atau memanfaatkan gambar/foto yang sudah ada dapat ditempelkan pada lembaran-lembaran (Yulianti, 2012:49).

Menurut Sardiman (2011:29) media gambar atau flashcard adalah media yang paling umum dipakai, dapat dimengerti dan dinikmati dimana-mana, memberikan bentuk gambar yang apa adanya, sehingga siswa mampu mengingatnya dengan lebih baik.

Berdasarkan latar belakang masalah dapat dirumuskan "Apakah melalui model pembelajaran Time Token berbasis media flashcard dapat meningkatkan aktivitas dan hasil belajar Ilmu Pengetahuan Alam materi perubahan lingkungan fisik pada siswa kelas IV SD Nganguk Semester II Tahun Pelajaran 2016/2017?" 
Tujuan penelitian ini adalah untuk menguji penerapan model Time Token berbasis media flashcard dapat meningkatkan aktivitas dan hasil belajar Ilmu Pengetahuan Alam materi perubahan lingkungan fisik pada siswa kelas IV SD Nganguk Semester II Tahun Pelajaran 2016/2017.

\section{Metode}

Subjek penelitian adalah siswa kelas IV SD Nganguk Semester II Tahun Pelajaran 2016/2017, berjumlah 23 siswa, siswa laki-laki sebanyak 15 siswa dan jumlah siswa perempuan sebanyak 8 siswa.

Penelitian yang dilakukan ini merupakan penelitian tindakan kelas yang terdiri dari dua siklus. Setiap siklus terdiri dari empat tahap yaitu perencanaan, tindakan, pengamatan, dan analisis atau refleksi (Arikunto, dkk. 2010:4).

Dalam perencanaan ini meliputi identifikasi masalah, menganalisis penyebab masalah dan menetapkan tindakan pemecahannya. Langkah selanjutnya membuat skenario pembelajaran dengan menyusun RPP yang terdapat proses pembelajaran model time token berbasis media flashcard. Pelaksanaan tindakan (acting) sesuai skenario pembelajaran yang direncanakan. Pada tiap-tiap siklus yaitu menerapkan pembelajaran model time token berbasis media flashcard. Siklus II merupakan hasil pengembangan atas refleksi hasil siklus I.

Pengamatan (observing) pada kegiatan ini peneliti dibantu oleh satu orang observer untuk melaksanakan observasi terhadap pelaksanaan tindakan untuk mengetahui sejauh mana penguasaan siswa dalam pembelajaran. Observasi dilaksanakan bersamaan pelaksanaan tindakan dengan menggunakan lembar observasi yang telah dibuat. Aspek-aspek yang diamati adalah keaktifan siswa dan kinerja guru selama proses pembelajaran berlangsung serta hasil tes pada akhir siklus. Hasil analisis data yang dilaksanakan dalam tahap ini digunakan sebagai acuan untuk melaksanakan siklus berikutnya.

Refleksi (reflecting) hasil observasi yang meliputi aktifitas siswa selama proses belajar mengajar, hasil tes pada akhir siklus juga kendala-kendala yang dihadapi selama kegiatan pembelajaran dikumpulkan serta dikaji sehingga diperoleh hasil refleksi kegiatan untuk mengetahui perubahan yang terjadi selama menerapkan pembelajaran ini. Hasil analisis data yang dilaksanakan dalam tahap ini digunakan sebagai acuan untuk melaksanakan siklus berikutnya.

Teknik pengumpulan data dengan mendeskripsikan hasil tes dilakukan secara langsung kepada siswa untuk memperoleh data tentang hasil belajar siswa pada proses pembelajaran secara benar dan tepat. Metode tes digunakan untuk memperoleh data tentang tingkat kemampuan penguasaan materi pembelajaran sebelum dan sesudah pembelajaran.

Teknik analisis melalui dua tahap, yaitu 1) menggunakan teknik analisis deskriptif yaitu hasil observasi kondisi awal, siklus I dan siklus II, sehingga setelah dianalisis hasil siklus I dan hasil siklus II ada perbedaan dan peningkatan; dan 2) menggunakan teknik observasi dengan analisis diskriptif berdasarkan hasil observasi dan refleksi untuk mengetahui kemajuan hasil yang dicapai dalam pembelajaran.

Data yang sudah terkumpul kemudian dianalisis untuk mengukur indikator keberhasilan yang telah dirumuskan yaitu: 1) untuk mengukur keaktifan siswa menggunakan kriteria secara klasikal mencapai kategori baik atau lebih dari 75\%; 2) hasil belajar IPA dianggap meningkat apabila dapat mencapai ketuntasan belajar individual sebesar ( $\geq 70)$ dan ketuntasan klasikal mencapai $80 \%$.

\section{Hasil dan Pembahasan}

Hasil penelitian tindakan kelas melalui model pembelajaran Time Token berbasis media flashcard yang diperoleh dari hasil tes dan nontes yang terlaksana dalam dua siklus. Setiap siklusnya dua kali pertemuan yang dapat meningkatkan kualitas pembelajaran yang berupa aktivitas belajar, dan hasil belajar siswa kelas IV SD Nganguk Kota Kudus.

Pada pelaksanaan kegiatan pembelajaran prasiklus, nilai tuntas belajar secara klasikal hasil belajar IPA kelas IV SD Nganguk Kota Kudus adalah 55,56\%, di bawah standar Kriteria Ketuntasan Minimal (KKM) yaitu taraf serap pencapaian target 70 secara individual dan $80 \%$. Kecenderungan perolehan nilai kriteria ketuntasan minimal kurang memacu peneliti untuk mengadakan tindakan penelitian serta merumuskan faktor-faktor penyebabnya untuk mencari solusi terbaik dengan hasil optimal.

Berdasarkan hasil tes formatif pembelajaran IPA pada siklus I melalui model pembelajaran time token berbasis media flashcard pada siswa kelas IV SD Nganguk Kota Kudus, diperoleh data sebagai berikut. 
Tabel 1. Hasil Belajar Siswa Siklus I

\begin{tabular}{clcccc}
\hline No & Rentang Nilai & Kategori & Frek & Nilai & Persen \\
\hline 1 & $91-100$ & SB & 2 & 200 & $11,11 \%$ \\
2 & $81-90$ & Baik & 4 & 355 & $22,22 \%$ \\
3 & $70-80$ & Cukup & 7 & 510 & $38,89 \%$ \\
4 & $\leq 70$ & Kurang & 5 & 260 & $27,78 \%$ \\
& Jumlah & 18 & 1325 & $100 \%$ \\
& Rata2 & & 73,61 & \\
& Tuntas & $\geq 70$ & 13 & & $72,22 \%$ \\
& Belum tuntas & $\leq 70$ & 5 & & $27,78 \%$ \\
\hline
\end{tabular}

Berdasarkan Tabel 1 diperoleh data bahwa ada 13 siswa atau sebesar 72,22\% mengalami ketuntasan belajar secara klasikal, sedangkan siswa yang mendapatkan nilai di bawah KKM secara klasikal ada 5 siswa atau sebesar 27,78\%. Dari tabel di atas dapat diketahui bahwa nilai rata-rata hasil belajar siswa pada awal sebelum pelaksanaan siklus sebesar 68,33 dengan nilai terendah 40 sedangkan nilai tertinggi 95, persentase ketuntasan sebesar 55,56\% dan $44,44 \%$ siswa belum memenuhi nilai ketuntasan minimal yang ditetapkan sebesar 70 . Setelah dilaksanakan siklus I nilai rata-rata menjadi 73,61 dengan nilai terendah 50, nilai tertinggi 100 . Persentase ketuntasan $72,22 \%$ dan $27,78 \%$ siswa belum memperoleh nilai ketuntasan minimal. Persentase ketuntasan belajar klasikal pada siklus I dapat disajikan dalam diagram berikut:

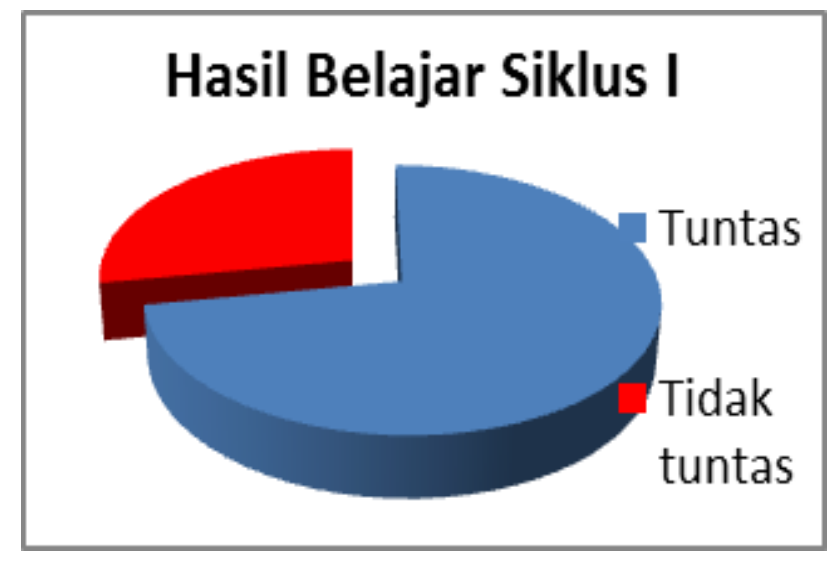

Gambar 1. Hasil belajar siklus I

Hasil pengamatan aktivitas siswa dalam proses pembelajaran model time token berbasis media flashcard memperoleh jumlah skor 17,61 dengan rata-rata 2,94 dan persentase 73,38\% termasuk aktivitas siswa dalam kualifikasi cukup baik. Dari data tersebut dapat disimpulkan bahwa hasil observasi aktivitas belajar siswa belum berhasil untuk mencapai indikator yang ditentukan pada aktivitas belajar siswa yaitu sebesar $\geq 75 \%$.

Hasil siklus I tersebut belum memenuhi indikator yang diharapkan, maka pembelajaran akan dilakukan lagi dengan memenuhi semua indikator pembelajaran model Time Token berbasis media flashcard, dengan harapan kualitas pembelajaran juga akan meningkat, maka perbaikan untuk pelaksanaan tindakan pada siklus II adalah sebagai berikut: 1) Perbaikan pemberian masalah yang berupa pertanyaan lisan terlebih dulu agar waktu pembelajaran lebih efektif; 2) Memberikan bimbingan dan motivasi dalam kegiatan kerja kelompok; 3) Meningkatkan motivasi siswa agar mau berpendapat pada setiap pertanyaan yang dilontarkan guru.

Kegiatan pembelajaran siklus II berlangsung sangat efektif, siswa antusias melakukan diskusi karena terjadi interaksi harmonis dalam satu kelompok maupun antar kelompok. Siswa saling menanggapi hasil temuan kelompok lain secara rasional dan berpendapat secara logis demokratis melalui model pembelajaran Time Token berbasis media flashcard.

Berdasarkan hasil tes formatif siswa kelas IV melalui model pembelajaran time token berbasis media flashcard diperoleh data sebagai berikut: 
Tabel 2.Hasil Belajar Siswa Siklus II

\begin{tabular}{cccccc}
\hline No & Rentang Nilai & Kategori & Frek & Nilai & Persen \\
\hline 1 & $91-100$ & Sangat baik & 4 & 400 & $22,22 \%$ \\
2 & $81-90$ & Baik & 5 & 445 & $27,78 \%$ \\
3 & $70-80$ & Cukup & 6 & 455 & $33,33 \%$ \\
4 & $\leq 70$ & Kurang & 3 & 180 & $16,67 \%$ \\
& Jumlah & & 18 & 1480 & $100 \%$ \\
& Rata-rata & & & 82,22 & \\
& Tuntas & $\geq 70$ & 15 & & $83,33 \%$ \\
& Belum tuntas & $\leq 70$ & 3 & & $16,67 \%$ \\
\hline
\end{tabular}

Berdasarkan Tabel 2 diketahui penerapan model pembelajaran time token berbasis media flashcard diperoleh data bahwa ada 15 siswa atau sebesar 83,33\% mengalami ketuntasan belajar $\geq 70$ sedangkan siswa mendapatkan nilai di bawah KKM secara klasikal $\leq 70$ ada 3 siswa atau sebesar $16,67 \%$. Persentase ketuntasan belajar secara klasikal pada siklus II dapat disajikan dalam diagram sebagai berikut:

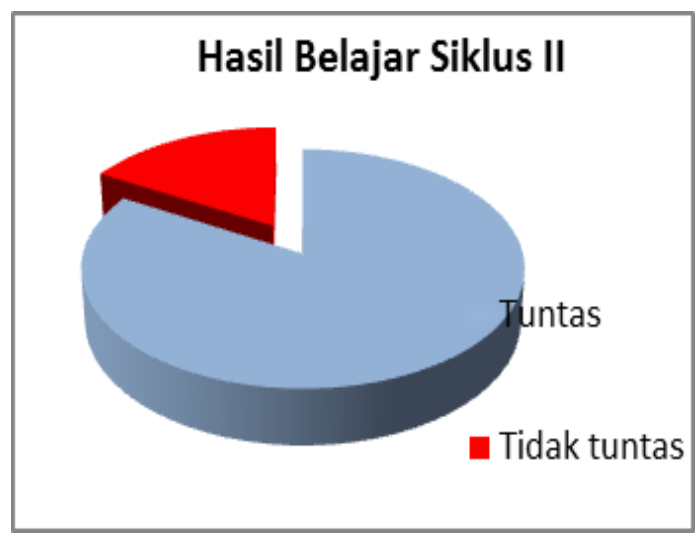

Gambar 2. Hasil belajar siklus II

Aktivitas belajar siswa pada tindakan siklus II mengalami banyak peningkatan dibandingkan saat siklus I, hal ini dapat dilihat dari hasil observasi aktivitas siswa pada siklus II pertemuan I sebesar 87,73\% dan pertemuan 2 sebesar 90,97\%. Dari kedua pertemuan tersebut didapatkan persentase rata-rata sebesar 89,35\%. Hasil aktivitas belajar siswa siklus II mengalami peningkatan dari 73,38\% menjadi 89,35\%. Hasil tersebut menunjukkan adanya ketercapaian indikator keberhasilan aktivitas belajar siswa yakni $\geq 75 \%$. Perolehan peningkatan nilai aktivitas siswa pada siklus II, karena peneliti sudah berhasil membuat siswa lebih memahami model pembelajaran Time Token berbasis media flashcard dengan penjelasan yang dilakukan oleh guru.

Pada pembelajaran sebelum tindakan penelitian, peneliti hanya mengandalkan metode konvensional yaitu ceramah, tanya jawab, dan pemberian tugas, sehingga hasil yang dicapai adalah siswa yang memperoleh nilai 70 ke atas hanya 10 dari 18 siswa atau 55,56\%. Dengan nilai terendah 40, nilai tertinggi 90 dan nilai rata-rata 68,33. Berdasarkan hasil tersebut peneliti bermaksud untuk meningkatkan aktivitas dan hasil belajar siswa tentang perubahan lingkungan fisik dengan melaksanakan model pembelajaran Time Token berbasis media flashcard.

Berdasarkan pelaksanaan tindakan pada siklus I, diperoleh data hasil belajar siswa kelas IV SD Nganguk Kudus dengan nilai rata-rata ketuntasan klasikal 72,22\%. Hasil tersebut menunjukkan peningkatan sebesar 16,66\% jika dibandingkan dengan data awal dengan ketuntasan klasikal sebesar $55,56 \%$. Perolehan hasil belajar siswa menujukkan bahwa dalam tes formatif nilai rata-rata kelas sebesar 73,61 dan presentase ketuntasan belajar klasikalnya mencapai 72,22\%. Nilai tertinggi 100 dan nilai terendah 50. Nilai ketuntasan minimal (KKM) 70. Perolehan hasil belajar belum memenuhi kriteria ketuntasan belajar klasikal yakni 80\%. Dari 18 siswa ada 13 siswa yang memenuhi nilai KKM dan masih ada 5 siswa yang mendapat nilai di bawah KKM. Dengan demikian masih ada 5 siswa yang belum mencapai KKM dan belum mencapai ketuntasan belajar klasikal.

Pada pembelajaran siklus II, penerapan model pembelajaran time token berbasis media flashcard pada materi perubahan lingkungan fisik mengalami peningkatan yang cukup baik. Hal tersebut dapat diketahui dari perolehan tes yang mengukur hasil belajar siswa menujukkan bahwa dalam tes formatif 
nilai rata-rata kelas sebesar 82,22 dan presentase ketuntasan belajar klasikalnya mencapai 83,33\%. Nilai ketuntasan minimal (KKM) yang telah ditentukan sekolah yaitu 70, sedangkan kriteria ketuntasan belajar klasikal yakni $80 \%$. Hal ini menunjukkan keberhasilan pembelajaran pada siklus II.

Secara visual peningkatan hasil belajar siswa pada siklus I dan siklus II dapat digambarkan pada diagram berikut.

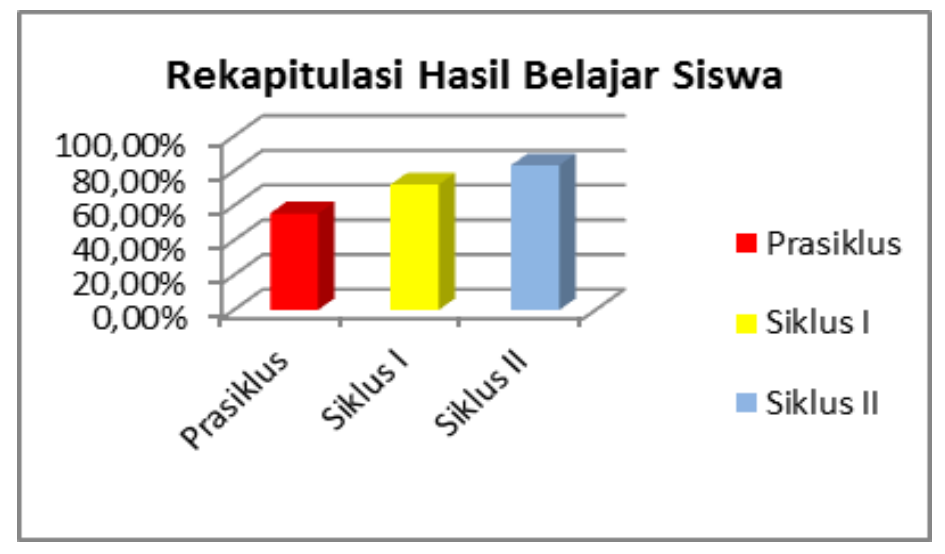

Gambar 3. Rekapitulasi Hasil Belajar Siswa

Pembelajaran IPA materi perubahan lingkungan menggunakan PBL juga dapat meningkatkan aktivitas siswa dari siklus I ke siklus II selama pelaksanaan tindakan pembelajaran.

Hasil observasi aktivitas siswa dalam mengikuti pembelajaran IPA materi perubahan lingkungan fisik melalui model Time Token berbasis media flashcard pada siklus I memperoleh skor 17,61 atau sebesar 73,38\% dengan kategori tinggi. Pada siklus II memperoleh jumlah skor 21,45 atau sebesar 89,35\% dengan kategori sangat tinggi. berikut.

Peningkatan aktivitas belajar siswa pada siklus I dan siklus II dapat digambarkan pada diagram

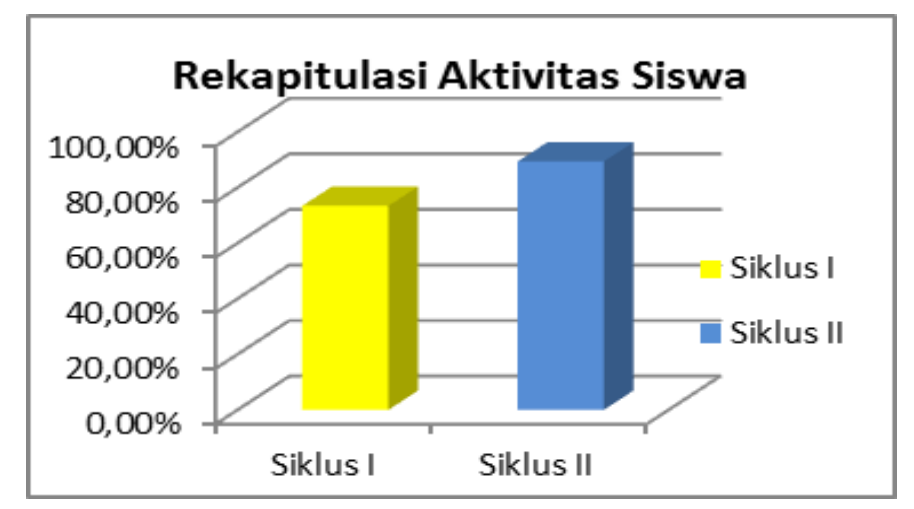

Gambar 4. Rekapitulasi Aktivitas Siswa

\section{Simpulan Dan Saran}

Berdasarkan hasil penelitian yang telah dilakukan dapat disimpulkan sebagai berikut: Dengan menerapkan model Time Token berbasis media flashcard, dapat meningkatkan aktivitas dan hasil belajar IPA materi perubahan lingkungan fisik pada siswa kelas IV SD Nganguk Semester II Tahun Pelajaran 2016/2017.

Penerapan model time token berbasis media flashcard pada mata pelajaran IPA materi perubahan lingkungan fisik di kelas IV SD Nganguk Kota Kudus mampu melatih keaktifan siswa dalam bertanya dan mengemukakan pendapat. Siswa akan berani untuk mempresentasikan hasil kerja kelompoknya secara klasikal serta dapat saling bekerja sama untuk membantu mengajari temannya yang kurang mampu memahami materi yang disampaikan oleh guru. 
Berdasarkan hasil penelitian tersebut, perlu kiranya penerapan model time token berbasis media flashcard sebagai strategi/model pembelajaran di sekolah-sekolah, untuk meningkatkan aktivitas dan hasil belajar IPA dan semua mata pelajaran yang lain pada umumnya.

Bagi lembaga pendidikan, hendaknya memberikan sarana dan prasarana, fasilitas serta motivasi bagi guru yang akan menerapkan model pembelajaran time token berbasis media flashcard atau model lain sehingga pembelajaran berlangsung optimal.

Bagi Guru, agar menerapkan model pembelajaran time token berbasis media flashcard ini dapat didayagunakan secara optimal, maka guru dalam setiap pembelajaran perlu merencanakan pendekatan atau strategi dan mempersiapkan media pembelajaran yang kreatif dan inovatif sehingga siswa menjadi lebih tertarik dan pembelajaran akan menjadi lebih kondusif dan bermakna.

Bagi siswa hendaknya penerapan model pembelajaran time token berbasis media flashcard selalu melaksanakan kegiatan pembelajaran dengan sebaik-baiknya. Pada setiap pembelajaran yang diberikan guru siswa seharusnya memperhatikan kerjasama untuk memecahkan suatu masalah dalam materi pembelajaran akan lebih mudah jika diselesaikan secara kelompok, dan siswa harus percaya diri dalam bertanya dan menjawab pertanyaan guru sehingga kegiatan pembelajaran berjalan dengan aktif dan tujuan pembelajaran dapat tercapai secara optimal.

\section{Daftar Rujukan}

Arikunto, S., Suhardjono, dan Supardi. 2010. Penelitian Tindakan Kelas. Jakarta: Bumi Aksara.

Ayuwanti, Irma. 2016. Meningkatkan Aktivitas Dan Hasil Belajar Matematika Menggunakan Model Pembelajaran Kooperatif Tipe Group Investigation Di Smk Tuma'ninah Yasin Metro . Jurnal SAP Vol. 1 No. 2 Desember 2016.

Dimyati dan Mujiono. 2010. Strategi Pembelajaran. Jakarta: Rineka Cipta

Huda, Miftahul. 2013. Cooperative Learning. Yogyakarta: Pustaka Pelajar.

Nasution, Mardiah Kalsum . 2017. Penggunaan Metode Pembelajaran Dalam Peningkatan Hasil Belajar Siswa . Jurnal Ilmiah Bidang Pendidikan Vol. 11, No. 1, 2017

Rifa'i, Achmad dan Catharina Tri Anni. 2009. Psikologi Pendidikan. Semarang: Universitas Negeri Semarang Press.

Sardiman.2011. Interaksi dan Motivasi Belajar Mengajar.Jakarta: Raja Grafindo Persada.

Sirait, Erlando Doni. 2016. Pengaruh Minat Belajar Terhadap Prestasi Belajar Matematika . Jurnal Formatif 6(1): 35-43, 2016

Trianto.2012. Mendisain Model Pembelajaran Inovatif-Progresif: Konsep Landasan, dan Implementasinya pada Kurikulum Tingkat Satuan Pendidikan (KTSP). Jakarta: Kencana Prenada Media Group.

Yulianti, Rani. 2012. Permainan yang Meningkatkan Kecerdasan Anak. Jakarta: Niaga Swadaya 